\title{
The Political Culture of Antebellum Iowa: An Overview
}

\section{ROBERT COOK}

THE POLITICAL CULTURE of the antebellum United States has been exercising historians ever since the professionalization of their discipline in the late nineteenth century. During the first half of the twentieth century most historians used traditional paradigms to explain the volatile politics of the 1840 s and $1850 \mathrm{~s}$. Focusing primarily on the activities of political elites, they explained support for the Whig, Democratic, and Republican parties in terms of the great national issues of the day-tariffs, banking, and the expansion of slavery, to name just three. ${ }^{1}$ After the Second World War, however, a growing interest in the social fabric of American politics spawned research into the dynamics of party affiliation at the grass roots. Much of that research focused on developments at the state or regional level. ${ }^{2}$

In 1961 Lee Benson's pathbreaking study of New York during the Jacksonian period stimulated a wide-ranging debate over the bases of popular participation in American politics during the formative years of the republic. Benson argued that partisanship in New York was largely a product of ethnicity and denominational attachment. Political organi-

I wish to thank my colleagues Dr. Sarah Barber and Dr. Richard Carwardine for their comments on a draft of this article.

1. Eric Foner, Free Soil, Free Labor, Free Men: The Ideology of the Republican Party Before the Civil War (New York, 1970), 1-10, is a useful brief introduction to the literature on the causes of the Civil War.

2. V. O. Key, Southern Politics in State and Nation (New York, 1949) was a pioneering study of voting behavior in a single region.

THE ANNALS OF IOWA 52 (Summer 1993). (CThe State Historical Society of Iowa, 1993. Adapted from Baptism of Fire: The Republican Party in lowa, 1838-1878, (C) Iowa State University Press, 1993. 
zations attracted voters not primarily because they adopted attractive policies but because their rhetoric, choice of candidates, and overall worldview meshed with a voter's experience and values. ${ }^{3}$

Benson's "ethnocultural" interpretation of New York politics challenged the traditional notion that antebellum voters cast their ballots as issue-oriented individuals. The cultural identity of groups, not support for antislavery or Henry Clay's American system, explained party affiliation. Although later works by Ronald Formisano, Paul Kleppner, and others confirmed the ethnocultural interpretation, it did not go unchallenged. Eric Foner's influential Free Soil, Free Labor, Free Men and Michael Holt's provocative analysis of politics in the 1850s, for example, cast doubt upon it by suggesting that voters were more issue-conscious than Benson and other ethnocultural historians claimed. ${ }^{4}$

By the early 1990s a new synthesis was beginning to emerge. That synthesis took into account the findings of the ethnoculturalists, but highlighted the links between party affiliation and economic change. Fusing the new cultural history (grounded in the writings of anthropologist Clifford Geertz and the British Marxist historian, E. P. Thompson), the emerging "republican synthesis," modernization theory, and the insights of the Benson school, historians such as Harry Watson, Charles Sellers, and Bruce Levine posited that while political affiliation in the antebellum period had diverse social, ideological, and economic roots, the key to understanding the era lay in a phenomenon called the market revolution. ${ }^{5}$ This helpful term-more comprehensive than George

3. Lee Benson, The Concept of Jacksonian Democracy: New York as a Test Case (Princeton, 1961).

4. Ronald P. Formisano, The Birth of Mass Political Parties: Michigan, 18271861 (Princeton, 1971); Paul Kleppner, The Cross of Culture: A Social Analysis of Midwestern Politics, 1850-1900 (New York, 1970); Foner, Free Soil, Free Labor, Free Men; Michael Holt, The Political Crisis of the 1850s (New York, 1978).

5. Clifford Geertz's contribution to the synthesis is encapsulated in "Ideology as a Cultural System," in David Apter, ed., Ideology and Discontent (New York, 1964), 47-76. Edward P. Thompson, The Making of the English Working Class (London, 1963), provided the model for several sparkling studies of early American labor, most notably Sean Wilentz, Chants Demo- 
R. Taylor's "transportation revolution," coined in the 1950sdenotes the transformation of the United States in the space of roughly seventy years (1790-1860) from a relatively simple, preindustrial society to an increasingly complex, modern economy. ${ }^{6}$

The agency of this transformation, commercial-industrial capitalism, had a critical impact on the institutions and social fabric of the nation, prompting seismic shifts in the loci of political and economic power, and forcing a rearrangement of the traditional bonds among individuals and groups alike. Master craftsmen became capitalist entrepreneurs; journeymen found themselves subsumed within the ranks of an incipient proletariat; and middle-class women were relegated to the domestic sphere. ${ }^{7}$ Joint stock corporations rose and fell with the economic cycles; increasing numbers of black slaves toiled on southern plantations to fuel the consumer boom in North America and Europe; and thousands of eastern farm families migrated westward to capitalize on the growing demand for foodstuffs. The nation's spatial and qualitative economic growth undermined the old certainties such as status and kinship networks by promoting occupational and geographical mobility. The inevitable search for security, order, and control led people to turn to new institutions or to

cratic: New York City and the Rise of the American Working Class, 17881850 (New York, 1984); and Bruce Laurie, Working People of Philadelphia, 1800-1850 (Philadelphia, 1980). For an introduction to the growing corpus of work on republican ideology in the United States, see Robert E. Shallhope, "Toward a Republican Synthesis: The Emergence of an Understanding of Republicanism in American Historiography," William and Mary Quarterly 29 (1972), 49-80; and Daniel T. Rodgers, "Republicanism: The Career of a Concept," Journal of American History 79 (1992), 11-38. The best attempt to analyze American development in terms of the modernization process is Richard Brown, Modernization: The Transformation of American Life, 1600-1865 (New York, 1976). The concept of the market revolution has been developed by, among others, Harry L. Watson, Liberty and Power: The Politics of Jacksonian America (New York, 1990); Charles G. Sellers, The Market Revolution and Jacksonian America, 1815-1846 (New York, 1991); and Bruce Levine, Half Slave and Half Free: The Roots of Civil War (New York, 1992).

6. George R. Taylor, The Transportation Revolution, 1815-1860 (New York, 1951).

7. On the evolution of the American working class, see Bruce Laurie, Artisans into Workers: Labor in Nineteenth-Century America (New York 1989). 
try to revitalize old ones. Churches, trade unions, masonic lodges, and political parties were swept by the winds of change as reformers and conservatives sought new agendas, notably, sabbatarianism, temperance, and land reform. A wave of Catholic immigration from Europe after 1830 added to the confusion. So too did the birth of the abolitionist movement in the same decade. In short, the latest historical research has revealed the market revolution to have been an agent of unparalleled social ferment, and one with important consequences for our understanding of antebellum politics.

Iowa, of course, participated fully in this transformation. In fact, its period of greatest demographic, economic, and institutional expansion coincided exactly with its encounter with the market revolution. Strangely, however, the state's antebellum political culture has been sadly neglected. Important monographs on individual politicians and the early Republican party do exist, but they do not answer the questions that historians of American party politics are now asking. ${ }^{8}$ The old debates over whether the state's Republican party was ideologically sound on the issue of race or whether its leaders were hand in glove with the railroads need recontextualizing in the wake of the new scholarship.

That is the task of this essay. Fortunately, in the past three decades scholars have produced a number of sophisti-

8. Morton Rosenberg, Iowa on the Eve of the Civil War: A Decade of Frontier Politics (Norman, OK, 1972), is the most reliable account of antebellum Iowa politics. Important, if old-fashioned, biographies include William Salter, The Life of James W. Grimes (New York, 1876), and Dan Elbert Clark, Samuel Jordan Kirkwood (lowa City, 1917). Other states have been better served, and Iowa itself has been the focus of important ethnocultural studies of the late nineteenth century. Significant studies of other states include Stephen L. Hansen, The Making of the Third Party System: Voters and Parties in Illinois, 1850-1876 (Ann Arbor, MI, 1980); Stephen E. Maizlish, The Triumph of Sectionalism: The Transformation of Ohio Politics, 1844-1856 (Kent, $\mathrm{OH}, 1983)$; Dale Baum, The Civil War Party System: The Case of Massachusetts, 1848-1876 (Chapel Hill, NC, 1984). Ethnocultural studies of politics in the late nineteenth century in which Iowa figures prominently include Richard J. Jensen, The Winning of the Midwest: Social and Political Conflict, 1888-1896 (Chicago, 1971); and Ballard C. Campbell, Representative Democracy: Public Policy and Midwestern Legislatures in the Late Nineteenth Century (Cambridge, MA, 1980). 
cated studies of the early Iowa economy. ${ }^{9}$ By synthesizing this literature with recent work on party politics in the antebellum United States, one can sketch the political culture of antebellum Iowa in a way that offers a fresh perspective for students of Iowa politics while adding Iowa's experience to the record of the national experience. The overview begins by investigating the impact of the market revolution on the trans-Mississippi West. Debates generated by the adaptation to" new market conditions reveal the fundamental dynamics of interparty competition during a period when expanding population and economic growth were transforming the face of the prairies. Jacksonian Democracy claimed the allegiance of a majority of Iowa voters in the $1840 \mathrm{~s}$, but material and ethnocultural divisions arising from the processes of change played a key role in promoting a relatively healthy two-party system on the west bank of the Mississippi River. This second party system broke down in the late 1840 s and 1850 s, however, undermined by escalating ethnocultural and sectional divisions. The third party system emerged in the late 1850 s and 1860 s out of the ruins of the second.

THE MARKET REVOLUTION came quickly to the wooded river valleys and open prairies of Iowa. The United States was barely a trans-Appalachian power when it emerged from the Revolution, and the Mississippi valley was a thinly populated region under the nominal control of France. Jefferson's purchase of Louisiana gave the new republic sovereignty over the country, but it remained thinly settled until population growth in the East, burgeoning European and domestic de-

9. Insightful modern studies of the early Iowa and midwestern economies include Allan G. Bogue, From Prairie to Corn Belt: Farming on the Illinois and Iowa Prairies in the Nineteenth Century (Chicago, 1963); Robert P. Swierenga, Pioneers and Profits: Land Speculation on the Iowa Frontier (Ames, 1968); idem, Acres for Cents: Delinquent Tax Auctions in Frontier Iowa (Westport, CT, 1976); Erling A. Erickson, Banking in.Frontier Iowa, 1836-1865 (Ames, 1971); Donald L. Winters; Farmers Without Farms: Agricultural Tenancy in Nineteenth Century lowa (Westport, CT, 1978); Jeremy Atack and Fred Bateman, To Their Own Soil: Agriculture in the Antebellum North (Ames, 1987); Timothy Mahoney, River Towns in the Great West: The Structure of Provincial Urbanization in the American Midwest, 1820-1870 (Cambridge, 1990). 
mand for foodstuffs (principally grain), and technological advances such as the steamboat and the cotton gin opened up the area to white settlement on a massive scale. Although whites had long been interested in the lead mines centered around Galena and Dubuque, colonization of the future territory of Iowa did not begin in earnest until after the Black Hawk Purchase of 1832. By 1844, the white male citizens of Iowa were ready to write their own constitution and apply for admission to the American Union. Granted generous borders by Congress in 1846, they prepared to make a garden of what, from their perspective, had hitherto been an unproductive wilderness. ${ }^{10}$

The market revolution had an immediate impact on Iowa, bringing about the rapid destruction of the indigenous civilizations. Tribes such as the Sauk and Mesquakie, the Winnebago and the Potawatomi found their self-sufficient, communal societies swept aside by the tide of white settlers who crossed the Mississippi after 1832. Within twenty years these tribes had been banished from Iowa. The few natives who remained were forced to make concessions to EuroAmerican mores. Even the fierce resistance of the Sioux had been broken by the time the Civil War began in $1861 .^{11}$ The tragedy of these peoples was not unlike that of other huntergatherers in other parts of the globe: the San in Cape Colony, the aborigines of Australia and Tasmania, the indigenous peoples of the Brazilian interior. All discovered that technology, demography, and disease were usually on the side of the white intruders and that the spirits of their ancestors were no match for crusading Christianity (Protestant or Catholic).

Replacing the hunting and gathering economies of the indigenous tribes was a dynamic form of commercial capitalism that had already begun to transform white communities back east. All of Iowa's early settlers had felt the effects of this new force: some, such as the agricultural migrants from New England and the South, may have been casualties; oth-

10. For a reliable account of the political and socioeconomic development of prestatehood Iowa, see Leland L. Sage, A History of Iowa (Ames, 1974), 52-79.

11. Ibid., 45-51, 58-59, 70-72, 107-8. 
ers, particularly farsighted merchants and eastern farmers with capital, had benefited from it. The economy the early settlers helped to construct was a complex and changing one, but its initial vitality lay in the export of foodstuffs. ${ }^{12}$ Farm prices were buoyant for much of the 1830 s and 1840 s, providing incentives for grain producers to purchase and improve fertile land in the West. With the federal government keen to dispose of public lands at relatively cheap prices, speculators with access to credit had no difficulty gaining control of vast acreages and selling them off to migrant farmers for a profit. At the same time that land sales were taking place, villages and towns began to spring up, first along the major river courses, then on the open prairies themselves. These urban centers competed vigorously for the export trade of the region, serviced the consumer demands of their hinterlands, and, in the case of the largest of them on the Mississippi, dispatched the foodstuffs to St. Louis or Chicago. By the late 1840 s, small cities such as Dubuque, Davenport, Keokuk, and Burlington were processing significant quantities of local meat and grain themselves.

THE SOCIAL STRUCTURE of the young state was determined largely by the expanding commercial economy of the upper Mississippi valley. At the top of the scale were, unsurprisingly, those with money and land: prosperous farmers in the countryside, wealthy merchants and lawyers in the towns. Each of these groups speculated heavily in real estate during the 1840 s, capitalizing on rising prices to build up and entrench their dominant position in society. ${ }^{13} \mathrm{~A}$ thriving mid-

12. The growth of commercial farming in Iowa is the subject of several studies, but see especially Mildred Throne, "Southern Iowa Agriculture, 1833-1890: The Progress from Subsistence to Commercial Corn-Belt Farming," Agricultural History 23 (1949), 124-30; Earle D. Ross, Iowa Agriculture: An Historical Survey (Iowa City, 1951), 12-50. Mahoney, River Towns, places early Iowa's economic development firmly in a regional context. For details of one of antebellum lowa's most significant food-processing industries, see Margaret Walsh, The Rise of the Midwestern Meat Packing Industry (Lexington, KY, 1982).

13. Swierenga, Pioneers and Profits, 101-2; Allan G. Bogue, "The Iowa Claim Clubs: Symbol and Substance," Mississippi Valley Historical Review 45 (1958), 231-53. 
dle class consisting of millers, commercial farmers, grocers, professionals, and skilled workers developed quickly as the fluid frontier gave way to more mature (if by no means rigid) patterns of settlement. Poorer squatters, itinerants, and unskilled farm and urban workers made up the lower sorts. Many of this latter group were European migrants. Irish Catholics were particularly conspicuous as manual laborers in the river cities; a few were free blacks from the Old Northwest and the upper South. ${ }^{14}$

Iowa's antebellum political leadership was composed largely of white males drawn from the upper and middle ranks of society. This too was hardly surprising. Wealth gave people access to education, connections, leisure time, and power. In geographical terms it made them more persistentmore committed to one particular location, less inclined to keep moving on in pursuit of the American Dream. ${ }^{15}$ Even though early Iowa was a rhetorically egalitarian and (in relative terms) politically democratic society, poor men seldom found their way into the state legislature, let alone the United States Congress. Notwithstanding Frederick Jackson Turner's frontier thesis, substantial settlers (be they self-made men or the beneficiaries of inherited wealth) dominated political life in Iowa during the antebellum years.

How did members of the state's socioeconomic elite manage to maintain their hold on power in an age when aristocratic notions and ostentatious shows of wealth were hardly de rigueur for aspiring officeholders? What, to rephrase the question in more scientific terms, were the key elements of linkage between elites and masses in early Iowa? To answer

14. No one has systematically analyzed class formation in antebellum Iowa. My comments here are derived principally from my own trawls through the 1850 and 1860 federal manuscript censuses. Relevant local studies include George A. Boeck, "An Early Iowa Community: Aspects of Economic, Social, and Political Development in Burlington, Iowa, 18331866" (Ph.D. diss. University of Iowa, 1961), chaps. 2, 4, 7, 10; and David W. Galenson and Clayne L. Pope, "Economic and Geographic Mobility on the Farming Frontier: Evidence from Appanoose County, Iowa, 18501870," Journal of Economic History 49 (1989), 635-55. On Iowa blacks before the Civil War, see James L. Hill, "Migration of Blacks to Iowa, 18201960," Journal of Negro History 66 (1966), 289-303.

15. Galenson and Pope, "Economic and Geographic Mobility," 644. 
this question properly we need to probe the political culture of the day, for this complex phenomenon conferred legitimacy upon government and thereby provided one of the most important social gels of the age.

THE STATE'S POLITICAL CULTURE was a dynamic one, forged out of a constant dialogue among the voters, their representatives, and, increasingly, the partisan press. One might even go so far as to say that the dialogue was as fertile as the soil on which it took place. Put simply, it consisted of a set of primary and secondary values. The primary values were shared in common by white Iowans and provided rich fiber for the growth of what was one of the most democratic societies in the western world in the middle of the nineteenth century. The secondary values were the roots of a highly competitive two-party system whose seeds had been blown across the Mississippi from the East.

The primary values need not detain us long. They were ones held by nearly all native-born white Americans in this period: a deep commitment to republican government, the sovereignty of the people, and the developing concept of meritocracy. The sources of these values were American nationalism and the Bible. All native-born Iowans had been reared on the myths of the Revolution-they knew from what their schoolteachers and parents had told them that the nation had been founded by heroes, that republican governments were superior to monarchies, and that the United States was a haven from the corruptions of the Old World. The vast majority of Iowans had no doubt, too, that there was a God-an inscrutable and capricious one, perhaps, but a God nonetheless. They knew this because they had been listening to stories from the Old and New Testaments since their birth. Denominational allegiance complicated matters, but every Iowan knew the worth of individual responsibility and self-discipline, even if they did not always practice what they had been taught. Republican and Christian values were reinforced by the growth of the new commercial economy: free labor capitalism meant that one had to sink or swim on one's own merits. Perhaps this had always been the case, even in preindustial societies. But at least in the old days 
communities and kinship networks had provided some kind of safety net. Nineteenth-century economic development continued to erode traditional society, forcing AmericansIowans included-increasingly to fall back on their own devices.

Local politics would have been a dull affair had they been shaped solely by these fundamental cultural values. What gave political conflict its edge on the prairies were the debates occasioned by commitment to these values. Everyone agreed that republicanism was a good thing, but how was republicanism to be defined? How was it to be protected in a rapidly changing world? Who was to protect it: government or the people themselves? Religion did much to shape Iowans' worldview, but what sort of Christian country was America, was Iowa, supposed to be? A Protestant one presumably, but which variant of Protestantism was to hold sway: evangelical or liturgical, Methodist or Baptist? Most people accepted that the influence of the market economy was healthy (it did after all lead to progress), but what role should the people and their representatives take in controlling and nurturing it? Should they, indeed, make any attempt to interfere with forces that many economists claimed had their own irrepressible dynamic? And what of the institutions thrown up by the market: banks, railroad corporations, and textile mills? Should they be left to their own devices, or should they be reined in as threats to the public good?

THE FIERCE INTERPARTY COMPETITION of the 1840s and 1850 s emerged from the debates over such broad questions and the secondary values they spawned. The parties themselves, some more influential and long-lived than others, exercised a remarkable influence over the lives of most Iowans from the territorial period onwards. They did so because most people-even women who could not voteperceived them as legitimate governing entities and effective media of public opinion.

Political parties did not gain legitimacy automatically, however. The only way the major organizations-Democrats, Whigs, and Republicans-secured it was by convincing sub- 
stantial sections of the electorate that they were representing the interests of the people and the republic. Each did this in rather different ways, but all tailored their appeals from the ideological cloth outlined above-specifically by identifying credible threats to Protestant-Republican values and institutions.

Jacksonian Democrats (regnant at first the territorial and then the state level until 1854) captured a majority of the electorate largely by pursuing a policy of negative government and free market economics. Government meddling in the affairs of the people, they argued, portended the kinds of tyranny perpetrated by the British before the Revolution. Democrats pointed to institutions such as the Second Bank of the United States and (closer to home) the Miners' Bank of Dubuque as evidence of corrupt power sources created by legislative fiat. ${ }^{16}$ Although by no means opposed to the commercial economy, they held that government should not immerse itself unduly in matters best left to market forces. In practical terms that meant that Democrats objected to granting special favors to individual transportation companies and were generally suspicious of banking corporations. The 1846 Iowa Constitution, a largely Jacksonian creation, prohibited Iowans from setting up banks within the confines of the state. ${ }^{17}$ The legal code of 1851 was another product of Democratic rule. It included a general incorporation law that ended the cumbersome practice of chartering joint-stock companies one by one. ${ }^{18}$

Iowa Democrats, like their copartisans in other regions of the United States, fought against governmental intervention in all walks of life, not just the economic sphere. In particular, they opposed efforts by evangelical Protestants to use governmental power to reform antebellum America's turbulent society in their own image. ${ }^{19}$ Campaigns to prohibit liquor

16. See Erickson, Banking in Frontier Iowa, 16-35, for an account of the Jacksonians' successful assault on the Miners' Bank.

17. Ibid., 47; Journal of the Convention for the Formation of a Constitution of the State of Iowa (Iowa City, 1846), 85-86.

18. Iowa Code $\S 43.10$ (1851).

19. Democratic resistance to evangelical interference in government was 
sales, abolish slavery, and maintain the sanctity of the sabbath were anathema to many Democrats because they smacked of interference in the lives of a free people. Far from promoting order and discipline, contended Jacksonians, such campaigns caused social unrest and, in the case of the abolition movement, threatened the very fabric of the Union. Expressing complete confidence in the people, these standard-bearers of laissez-faire explicitly rejected the notion that economic growth and moral reform required the heavy hand of government.

Whigs were not convinced by such reasoning. In their view Iowa could not hope to take full advantage of eastern demand for western grain without federal and local government aid. The Whigs' central contention was that notwithstanding the fertility of the prairies, the land was valueless until it was first improved-tilled, fenced, and well-stocked with animals-and then linked to the market by an efficient financial and transport infrastructure. Iowans needed plank roads, navigable rivers, railroads, banks, and credit. Without these accoutrements of a modern economy, they would surely lose out in market competition with the inhabitants of other western states. The prairies would remain a wilderness unless they were integrated properly into America's expanding commercial nexus by public-spirited legislators and judges. ${ }^{20}$

Throughout their party's short-lived existence (1840-c. 1855), Iowa Whigs campaigned relentlessly for public assistance to be given to fledgling corporations (banks, railroads, and milling companies). They fought to obstruct the Democrats' assault on the Miners' Bank of Dubuque and unreserv-

highlighted at the 1844 constitutional convention when Jacksonian delegates resisted a Whig motion to open the daily proceedings with prayer. Benjamin F. Shambaugh, Fragments of the Debates of the Iowa Constitutional Conventions of 1844 and 1846 ... (Iowa City, 1900), 21-22.

20. The best introduction to Iowa Whiggery remains Louis Pelzer, "The History and Principles of the Whigs of the Territory of Iowa," Iowa Journal of History and Politics 5 (1907), 46-90. On the ideology of the national Whig party, see Daniel W. Howe, The Political Culture of the American Whigs (Chicago, 1979). For a representative summary of Whig economic policy in the 1840s, see William Penn Clarke's critique of the 1846 constitution in Howe, Political Culture, 349-52. 
edly welcomed the railroad as the harbinger of modern civilization. ${ }^{21}$ Like the Jacksonians, they too extended their philosophy of government into the private sphere. Having rather less confidence in the masses than their opponents, however, Whigs tended to favor using the legislature and courts to enforce basic standards of Protestant morality. Much (though by no means all) of the support for the so-called blue laws against gambling, desecration of the sabbath, and drinking came from Whigs. ${ }^{22}$ So too did the modicum of legislative opposition to the state's virulently racist stance on black in-migration. ${ }^{23}$

Race, in fact, was an integral element in the political culture of the day. ${ }^{24}$ Both major parties in the 1840 s were racist, but while the Democrats were virulently Negrophobic, Whigs tended to be more paternalistic in their attitude towards blacks. This was partly a consequence of their different constituencies, but also a result of their divergent views of society. The Democrats' broad definition of political society (all adult white male citizens of the republic) was only possible

21. Whig support for the Miners' Bank was evident in the 1844 Iowa House when James Grimes of Burlington fought to introduce a substitute bill designed to stave off repeal of the bank's charter. 1844 Iowa Territorial House Journal, 76. Whig strength in the Council (the upper house) gave the bank a temporary stay of execution, but a Democrat-controlled legislature killed off the institution the following year.

22. Iowa House Whigs voted 10-1 to support an act to punish gaming in 1843. 1843 Iowa Territorial House Journal, 190. In the same session of the Iowa legislature, Whig support for a sabbatarian bill was consistently stronger than that of their opponents. Ibid., 129, 134-35; and 1843 Iowa Territorial Council Journal, 104, 117. Iowa Whigs publicly endorsed temperance at their state convention in February 1854. Herbert S. Fairall, The Iowa City Republican Manual of Iowa Politics (Iowa City, 1881), 38. They gave almost full support to a prohibitory liquor law at the ensuing session of the General Assembly. 1855 Iowa Senate Journal, 201; and 1855 Iowa House Journal, 229-30. Although these measures would not have passed without Democratic support, Jacksonian members provided the bulk of opposition to each of them.

23. The Iowa legislature restricted the entry of blacks into the territory in 1839. Whig opposition to the law is noted in Robert R. Dykstra, "White Men, Black Laws: Territorial Iowans and Civil Rights, 1838-1843," Annals of Iowa 46 (1982), 422.

24. See Robert R. Dykstra, Bright Radical Star: Black Freedom and White Supremacy on the Hawkeye Frontier (Cambridge, MA, 1993). 
because they excluded a wide range of groups from it. ${ }^{25}$ Positing the inferiority of African-Americans (as well as American Indians) made it easier for them to claim that all white men were equal under the law. The more conservative Whigs possessed a hierarchical, but in some ways more inclusive, worldview that encompassed "inferior" races, although the former were in no doubt that the vast majority of such peoples were destined to occupy a position at the foot of the social scale (perhaps with a few lower-class whites who had failed to better themselves). The Democrats' preoccupation with race, however, made them much more tolerant of poverty-stricken European immigrants than the Whigs, whose suspicion of the lower sorts frequently rendered them xenophobic. ${ }^{26}$ Religious divisions exacerbated racial and ethnic differences between the two parties in Iowa. Many evangelical Whigs advocated the use of government to create a truly Protestant republic-by preventing liquor sales, for example, or (in rather fewer cases) by opposing the state's official endorsement of white supremacy. They were therefore inclined to oppose the rising political influence of Irish Catholics, for the latter were renowned for their drinking and reluctance to support the crusade against slavery. ${ }^{27}$ Democrats, on the other hand, endorsed cultural pluralism as a vital component of republican ideology and rejected Whig criticisms of foreign immigrants.

More township-level research needs to be done on the precise nature of the two major parties' constituencies in

25. John Ashworth, "Agrarians" and "Aristocrats": Party Political Ideology in the United States, 1837-1846 (London, 1983), 221-23. Ashworth concedes that Jacksonian theory was unable to encompass African-Americans, but he deemphasizes racism as a component of the Democrats' worldview. Jean Baker, Affairs of Party: The Political Culture of Northern Democrats in the Mid-Nineteenth Century (Ithaca, NY, 1983), 212-58, redresses the balance.

26. Bruce Collins, "The Ideology of the Ante-bellum Northern Democrats," Journal of American Studies 11 (1977), 103-21, stresses the Democrats' emphasis on cultural pluralism.

27. The links between temperance and nativism are explored in Ronald $\mathrm{F}$. Matthias, "The Know Nothing Movement in Iowa" (Ph.D. diss., University of Chicago, 1965), chap. 1. 
Iowa. ${ }^{28}$ We know enough, however, to sketch the social and ethnic composition of both the leadership and their partisan supporters. Whig and Democratic leaders were generally wealthy men-mostly attorneys from the eastern and southern states who speculated heavily in real estate or at the very least found the law a remunerative profession in a frontier region beset by rival land claims and horse thieving. Most of them had been born in the United States, had received an above average education, and resided in the larger urban centers of the state. ${ }^{29}$ These factors gave them enormous advantages over the vast majority of their constituents; towndwelling, for example, made them more cosmopolitan, more aware of what was happening in the world around them, and placed them closer to the main concentrations of capital in both the state and the nation. As boosters, they were frequently at the center of the intense interurban competition for the trade of the backcountry that took place in Iowa before the Civil War. Prominent lawyers such as Charles Mason and James Grimes, for example, endeavored to place their home town of Burlington ahead of Keokuk in the race for railroad connections to the East. ${ }^{30}$ The fact that Mason was a committed Democrat and Grimes a rising star in the local Whig party indicates the prevalence of intraelite cooperation behind the scenes. All Iowans shared a commitment to economic growth (not to mention personal profit), but politically active lawyers and their mercantile allies were better placed than most settlers to benefit from the processes of change.

28. The importance of applying multivariate techniques to random township data in order to determine grass-roots voting behavior is stressed by J. Morgan Kousser, "The 'New Political History': A Methodological Critique," Reviews in American History 4 (1976), 1-14. Township statistics figure prominently in Dykstra, Bright Radical Star.

29. See the sketches in Edward H. Stiles, Recollections and Sketches of Notable Lawyers and Public Men of Early Iowa (Des Moines, 1916).

30. See, for example, James Grimes to Charles Mason, 13 February 1852, Charles Mason Papers, State Historical Society of Iowa, Des Moines. 
The parties' constituents were a polyglot bunch. ${ }^{31}$ In ethnoreligious terms, the Democrats fared better among European immigrants than the Whigs: Catholic Irish and Germans were particularly devoted to the Jacksonian cause, partly because the Democrats appeared to be less ethnocentric than the Whigs, and partly because the Whig party was perceived as a vehicle for bigoted evangelical Protestantism. Many of the upcountry southerners who migrated to Iowa in the late 1830 s and 1840 s were also Democrats, principally because they had opposed the dominance of large Whig slaveholders in states such as Tennessee and Virginia. Many of these people were Baptists and Methodists, and were naturally suspicious of the more Yankeefied denominations that were at the forefront of moral reform in the antebellum period, principally Congregationalists and Presbyterians. In Iowa, hard-pressed Whigs drew a good deal of support from members of these latter churches, as well as from areas of Quaker settlement, such as Henry County in the southeast. New Englanders and British immigrants appear to have favored the Whig party, too, not only because of its moral concerns but also due to its generally Anglophile ethos.

Class, too, may have played an important role in Iowa politics before the mid-1850s. Although we know that the leaders of both parties came from the middling and upper ranks of society, there is no hard evidence to show that wealth and status seriously affected partisan attachments among ordinary voters. However, work on political affiliation in other American communities during the antebellum period does indicate that Whigs performed better in urban areas and

31. There is no ethnocultural analysis of voting behavior in antebellum Iowa. My speculative remarks in this paragraph are therefore based on various studies of Jacksonian politics, especially Watson, Liberty and Power, 194, 222-23; Richard Carwardine, "Evangelicals, Whigs and the Election of William Henry Harrison," Journal of American Studies 17 (1983), 47-75; and Kleppner, Cross of Culture, chap. 3. William E. Gienapp, The Origins of the Republican Party, 1852-1856 (New York, 1987), 423-39; George H. Daniels, "Immigrant Vote in the 1860 Election in the Case of Iowa," in Frederick C. Luebke, ed., Ethnic Voters and the Election of Lincoln (Lincoln, NE, 1971), 110-28; and Robert P. Swierenga, "The Ethnic Voter and the First Lincoln Election," ibid., 129-50, support the view that there was a strong ethnic and religious basis to popular voting behavior in antebellum Iowa. 
attracted a disproportionate amount of support from relatively prosperous individuals integrated into the market economy. ${ }^{32}$ Without township-level data it is impossible to say whether a similar pattern was evident in early Iowa. The best one can do is note that Whig and Democratic rhetoric was redolent of class divisions. Democrats attacked their opponents as aristocrats and tools of eastern capital; they poured flattery on ordinary settlers, courting the votes of workingmen and independent-minded farmers. ${ }^{33}$ Whigs, on the other hand, spoke of a harmony of interests among classes, and publicly identified themselves with banks and manufacturers. ${ }^{34}$ Such rhetoric clearly hinted at differences of status and wealth between the parties' constituencies, although ethnocultural divisions almost certainly cut across class lines.

The main elements of interparty competition in Iowa during the years of the second party system were thus economic and ethnoreligious in origin. Arguably, however, it was the system's primary focus on economic concerns that kept the Democrats in power for so long. Specifically, their advocacy of liberal land policies for western settlers (explicit in their vocal support for a generous preemption law and implicit in their vision of a republic of self-reliant yeomen farmers) proved exceptionally popular with the electorate. ${ }^{35}$ Even though the Whigs recognized the need to appeal to the people in the same obsequious terms as the Democrats, they never quite succeeded in casting off their image as social conservatives. Whig strategists clearly hoped that their endorse-

32. Watson, Liberty and Power, 236; Paul Goodman, "The Social Basis of New England Politics in Jacksonian America," Journal of the Early Republic 6 (1986), 36-37.

33. For example, the 1841 Democratic platform attacked the Whigs as blue-stockinged "Federalists," supported the passage of a preemption law to safeguard the rights of "the hardy pioneer," and called for the destruction of the Bank of the United States. Fairall, Manual of Iowa Politics, 12-13.

34. Iowa Whig platforms in the 1840 s consistently expressed support for high tariffs (to boost domestic industry), government aid for internal improvements, and banks of issue. Ibid., 14, 16-17, 22-23.

35. Democratic support for preemption was a key feature of the party's 1841 election platform. Ibid., 12-13. 
ment of economic growth and the institutions necessary to promote it would capture the imagination of the public. Would not everyone benefit, they reasoned, if the economic pie got bigger thanks to the banks, the transportation companies, and, of course, the hard work of those who tilled the soil? The answer may well have been yes, but in an age when the Money Power was regarded as a serious threat to republican liberties, such an argument was destined to fall on stony ground.

Part of the problem was that the national Whig party was manifestly unsympathetic to a generous policy of land distribution in the West, but lowa Whigs were also hindered by the fact that the local economy was still immature enough to permit their opponents to lambast banks and other corporations as monopolistic and predatory. ${ }^{36}$ When, in the late 1840 s, population did expand beyond the immediate confines of Iowa's navigable rivers and eastern railroads began to approach the Mississippi, Whig party leaders found their materialistic appeals undercut by the readiness of many Democrats to tone down their agrarian rhetoric and welcome the advent of the iron horse ${ }^{37}$ For the truth was that at first all Iowans, regardless of their partisan allegiance, regarded the railroads as a godsend. The new technology promised to reduce the costs of transporting their foodstuffs to market (most likely to Chicago, the emerging hub of the midwestern economy, rather than to St. Louis) as well as to increase the value of their property. Small wonder enthusiastic Iowa farmers began voting local tax aid to railroads as soon as they were given the opportunity in the early $1850 \mathrm{s.}^{38}$

It is not easy to determine the role of issues in the political culture of the day, but the careful thought that went into drawing up election platforms suggests that the politicians themselves were in no doubt that the voters responded to

36. For Jacksonian attacks on banking in the 1844 constitutional convention, see Shambaugh, Debates, 69-70.

37. Democratic support for railroads is detailed more fully in Robert Cook, Baptism of Fire: The Republican Party in Iowa, 1838-1878 (forthcoming, Ames, 1993), chap. 2.

38. John Lauritz Larson, Bonds of Enterprise: John Murray Forbes and Western Development in America's Railway Age (Cambridge, MA, 1984), 59. 
more than just the sign-ridden language of their speeches. Iowans rejected the constitution of 1844 because they wanted larger borders for their state and (in some cases) a continuation of low territorial property taxes. ${ }^{39}$ Nor was it only local issues to which they responded. When voters dumped the Democrats in 1854, their decision was linked to their anger at that party's congressional support for the despised KansasNebraska Act. ${ }^{40}$ Of course, issues were often related to value systems-evangelical Protestantism, Roman Catholicism, working-class republicanism-but early Iowans were a practical people who wanted something more than symbolic gestures from their representatives at Iowa City and Washington. If those representatives did not respond to their wishes, then they could always be ousted at the polls.

All this should not be taken to mean that a perfectly democratic relationship existed between the leaders and the led. Early Iowa was clearly not some kind of Turnerian frontier utopia. Most antebellum political parties sought power not only to formulate policy but also to capture the spoils of office. The United States at midcentury possessed no real bureaucracy at the state or federal levels. The day-to-day operation of government was carried out by political appointees aided by a few clerks who owed their position to the workings of the patronage system. Loyal party workers in townships across the state expected to gain some reward if their organization triumphed at the biennial elections for governor and legislature. Having attached themselves to, say, a member or prospective member of the General Assembly, they would then require the successful individual to promote their efforts to become a federal postmaster at home or (in the case of newspaper editors) win a contract to print public documents. Officeholders further up the party hierarchy could use their positions to establish profitable connections with merchant capitalists (politicians in office were always useful to eastern railroad magnates and local merchants) and, by dispensing patronage as judiciously as possible, build up

39. Sage, History of Iowa, 84-88.

40. Cook, Baptism of Fire, chap. 2; Rosenberg, Iowa on the Eve of the Civil War, chap. 4. 
durable power bases in Iowa. Factionalism was an obvious consequence of the spoils system, for disappointed office seekers were often swift to join alternative power networks in an effort to feed at the public trough. The Dubuque Democratic party, for example, was riven by a dispute between rival politicos during the late $1850 \mathrm{~s}^{41}$

The struggle for spoils was fierce throughout the antebellum years and makes it harder to pinpoint the motivation behind all the speeches and platform-making of the day. Was the rhetoric of conspiracy, reform, and economic growth genuinely policy-oriented, or was it really a smokescreen behind which ambitious politicians could advance their own selfish projects? There is no easy answer to this question. Some individual Iowa politicians did regard politics as little more than a game; "it's like ratting-fun," remarked one of them. ${ }^{42}$ Such men may have had little commitment to the ideal of representative democracy or to the stated policies and values of their party. That was probably not the case with most antebellum politicians, however. All Iowa politicians were ambitious-either for themselves, their cause, or most probably both. That is hardly surprising, for they were, on balance, no more nor less altruistic than their constituents. What is striking is the degree of their loyalty to party; surprisingly few Whigs, for example, regarded their organization's persistently poor electoral performances as an excuse to jump ship and run as Democrats. That was not simply because they feared being exposed as traitors or "soreheads," but rather because they had a strong sense of party allegiance. Values as well as office motivated the majority of Iowa politicians before the Civil War.

SUSTAINED AS IT WAS by such a diverse political culture, why did the second party system begin to disintegrate in Iowa in the late 1840 s? Two major factors were to blame: the increasing seriousness of the sectional conflict between North and South; and a rise in prominence of ethnocultural issues

41. Rosenberg, Iowa on the Eve of the Civil War, 172.

42. James Thorington to William Penn Clarke, 3 January 1857, William Penn Clarke Papers, State Historical Society of Iowa, Des Moines. 
which began to undermine popular faith in the existing political structure.

lowa politics-even in the 1840 s, when communications with the rest of the United States were relatively primitivewas by no means isolated from national affairs. Western voters were perfectly capable of responding to developments occurring beyond the boundaries of the state: local papers were full of national news and editorials telling them what to think about the great issues of the day-the Mexican War, the crisis with Britain over Oregon, the debates in Congress preceding the Compromise of 1850. Party platforms bristled with planks about such faraway happenings, for party strategists were well aware that it took more than the Miners' Bank of Dubuque or the Scott County Hydraulic Company to mobilize the voters. ${ }^{43}$ As Michael Holt has rightly pointed out, issue generation was what antebellum politics was all about. ${ }^{44}$ Without issues, voters could become dissatisfied and lose interest in politics and politicians.

On balance, the Democrats got the best of the national debate in the 1840s. Their emphasis on spatial rather than qualitative economic expansion, confident assertions of American nationalism, and glorification of the white republic appealed more to pioneering folk than the Whigs' constant harping on the need for government-aided economic growth. What weakened the Democrats' grip on power in Iowa was (a) their reliance on the southern wing of the party at a time when northerners were growing fearful of proslavery efforts to undermine their liberties and (b) the destruction of the minority Whig party and its replacement by a much more formidable opposition.

Although both of these developments were connected, the second was not wholly a product of the first. The Whig party collapsed because its political leaders could not turn changes within the political culture of the state to their own advantage-at least not within the straitjacket imposed by the existing party system. Growing population in the counties

43. See Fairall, Manual of Iowa Politics, 11-28, for Whig and Democratic platforms in the 1840 s.

44. Holt, Political Crisis, 102-3 and passim. 
west of the Mississippi and the inevitable maturation of what had once been a rather crude frontier society prompted increased support for the machinery of a modern economy. The Whigs should have been able to make something of this, but they found their efforts blocked by the readiness of the Democrats to welcome the advent of the railroads from the East and, in some cases, to support the removal of the constitutional prohibition of banking. ${ }^{45}$ At the same time, Whig leaders were confronted with insistent calls from their evangelical wing to legislate against liquor sales, put an end to the desecration of the sabbath, and provide a stronger bulwark against the dictates of the South. These demands drove a wedge between National Whigs (supporters of the 1850 Compromise who generally abhorred agitation over "moral" questions because of their divisive impact on the Union and the party) and Free Soil Whigs, who believed not only that the time had come to stand up to the blustering of southern slaveholders, but also that an alliance with Iowa's small band of political antislavery men could make the difference between electoral success and failure.

At first it seemed that the fusionist strategy of the Free Soil Whigs might liberate the state from the thraldom of the Democrats. Adverse public reaction to Stephen Douglas's attempts to abrogate the sacred Missouri Compromise early in 1854 resulted in a Whig-Free Soil alliance prior to the gubernatorial contest of that year. ${ }^{46}$ The antislavery Whig, James Grimes, won a narrow majority on the basis of his opposition to the Kansas-Nebraska Act and an unashamedly Whiggish campaign address extolling the virtues of positive government. ${ }^{47}$ No sooner had the Whigs finished celebrating this dramatic victory, however, than their dreams of political hegemony were shattered by an upsurge of political nativism directed against Roman Catholic immigrants.

45. Erickson, Banking in Frontier Iowa, 96.

46. Sage, History of Iowa, 127-28.

47. The most recent and most sophisticated account of Grimes's gubernatorial victory is in Gienapp, Origins of the Republican Party, 121-22. 
The Know Nothing party's reign in Iowa was brief but eventful. ${ }^{48}$ Drawing impressive support during 1855 from American-born artisans in the river towns, anti-Catholic evangelicals, and southern migrants, the new party called for curbs on the political and social influence of Catholic immigrants. Although Whig leaders had always evinced some sympathy for nativism (not least because so many of the foreigners voted Democrat), their desire to win over Protestant Germans tended to mitigate their xenophobia. Thus, with the Democrats generally sympathetic to the immigrants, frustrated Iowans had only the Know Nothings to turn to when they found Catholic immigrants threatening both their jobs and their cultural hegemony. Politicians from the major parties were quick to jump on board the nativist bandwagon, for it seemed that the latter would carry all before it. Remarkably, however, the Know Nothings vanished as quickly as they had appeared. They did so because a much more durable and powerful force came into its own during the winter of 1855-56. That force was political antislavery.

The Republican party of Iowa was founded in February $1856 .{ }^{49}$ Its central tenet was simple: opposition to the spread of slavery in the United States. Slavery had not bothered most white Iowans during the 1840 s and early 1850 s. Few of them liked it, but hardly anyone save a few abolitionists and Free Soilers wanted to endanger the Union by campaigning against it. What changed this reluctance to upset the apple cart was the growing perception among all northerners, not just Iowans, that the South was attempting to impose its immoral and backward institution on the rest of the country. Northerners thought that such an attempt, evidenced by the passage of the new Fugitive Slave Law and the KansasNebraska Act, amounted to a perversion of the ideals on

48. The only full-length account of political nativism in Iowa is Matthias, "Know-Nothing Movement in lowa."

49. The best accounts of the formation of the Republican party in Iowa are Louis Pelzer, "The Origins and Organization of the Republican Party in Iowa," Iowa Journal of History and Politics 4 (1906), 487-525; and David S. Sparkes, "The Birth of the Republican Party in Iowa, 1848-1860" (Ph.D. diss., University of Chicago, 1951), chaps. 4-5. 
which the republic had been founded and threatened the livelihood of free, independent citizens. ${ }^{50}$

The once preposterous notion that a tiny group of wealthy planters-the "slave power" in contemporary parlance-was plotting to destroy the rights of northerners took on added significance in late 1855 when a fierce guerrilla war involving free state and proslavery forces erupted in neighboring Kansas. ${ }^{51}$ That conflict presented leaders of the embryonic Republican coalition with the proof they had been looking for-proof that southern planters and their northern Democrat allies were engaged in a vast conspiracy to spread slavery across the United States. To a large extent, then, Iowa's Republican strategists (most of whom had been Free Soil Whigs) were able to capitalize on popular fears and expectations that hitherto had helped keep the Democrats in office for so long: antipathy toward "aristocrats," concerns for the welfare of free white labor, and a profound suspicion of unrestrained power.

Opposition to the extension of slavery did not constitute the only string to the Republican bow, however. Land reform, a protective tariff, support for banking and railroads, tighter voting restrictions on immigrants, qualified endorsement of temperance, and even a popular referendum on black suffrage were all designed to add to the party's electoral appeal between 1854 and $1860 .{ }^{52}$ Such policies were carefully crafted to win over different sections of the electorate except voters who made up the Democrats' core constituency. Protectionism and watered-down nativism, for example, appealed to artisans in the river towns; endorsements of prohibition and other moral reforms attracted mainstream evangelical Protestants; and banking reform (backed by Republi-

50. James Grimes capitalized on these themes in his address "To the People of Iowa," issued in the early stage of his 1854 gubernatorial campaign. See Salter, Life, 39-50.

51. The role played by Kansas in Republican electoral successes during the mid-1850s can be traced in Rosenberg, Iowa on the Eve of Civil War, chaps. 9-10; Sparkes, "Birth of the Republican Party," 146; and Cook, Baptism of Fire, chap. 3.

52. For Republican platforms, 1856-1860, see Fairall, Manual of Iowa Politics, 40-41, 42-44, 46-51, 54 . 
can delegates at the 1857 constitutional convention in Iowa City) must have been music to the ears of commercial farmers desperate for reliable credit and currency facilities. ${ }^{53}$ But in the final analysis it was the Republicans' careful use (their opponents would have said "manipulation") of the slave power argument that enabled coalition builders to overcome the Know Nothing challenge, broaden the base of the old Whig constituency, and finally convert the new organization into the majoritarian force in local politics. ${ }^{54}$

Iowa Democrats struggled hard in the late 1850 s to regain their lost ascendancy. They sought to convince voters that the Republicans were abolitionists, disunionists, and advocates of miscegenation and to reactivate the former Jacksonian coalition by attacking banks and Yankee moralists. ${ }^{55}$ Time and events, however, were against them. Commercial farmers wanted an economic infrastructure fit for the middle of the nineteenth century. The Republicans' Whiggish emphasis on positive government was thus much more conducive to their aims than the seemingly outmoded laissez-faire policies of the Jacksonians. More significant than this, however, was the fact that the South appeared to grow even more hostile in the second half of the 1850s. The caning of Charles Sumner, the national Democratic administration's ill-judged attempts to impose a proslavery settlement on Kansas, the Dred Scott decision, and aggressive southern calls for a federal slave code for the territories did nothing to convince Iowans that popular sovereignty-the Douglas Democrats' local solution to the slavery question-was a solid enough bulwark of northern rights. When war came in April 1861, Iowa Democrats had little choice but to support the newly

53. Erickson, Banking in Frontier Iowa, 90-91; Sage, History of Iowa, 13349. Counties specializing in wheat production for the market were among those switching from the Democrats to the anti-Nebraska coalition in the 1854 gubernatorial election.

54. On the Republicans' use of slave power rhetoric, see William E. Gienapp, "The Republican Party and the Slave Power," in Robert H. Abzug and Stephen H. Maizlish, eds., New Perspectives on Race and Slavery: Essays in Honor of Kenneth M. Stampp (Lexington, KY, 1986).

55. Cook, Baptism of Fire, chaps. 4-6; Rosenberg, Iowa on the Eve of the Civil War, chaps. 9-10. 
elected Republican government of Abraham Lincoln. Their world had turned upside down.

Antebellum Iowa's political culture was thus as vibrant as the times. Economic change and ethnic variety, sectionalism and nationalism, republicanism and racism all combined to promote fierce interparty competition in the region by providing political elites with a roster of concrete issues and value-laden totems which they employed to mobilize the people. Hindsight, however, reveals that a high price had to be paid for such richness. After thirteen thousand patriotic Iowans perished in the ensuing struggle to prevent southern slaveholders from destroying the American Union, a sterile political culture grew up rapidly around Iowa's Grand Old Party. Relying heavily on past glories, Republicans went on to dominate state politics for nearly three-quarters of a century. Aside from a brief flirtation with power between 1889 and 1893, local Democrats would not taste lasting political success again until the advent of the New Deal. 
Copyright of Annals of Iowa is the property of State of Iowa, by \& through the State Historical Society of Iowa and its content may not be copied or emailed to multiple sites or posted to a listserv without the copyright holder's express written permission. However, users may print, download, or email articles for individual use. 